\title{
Analisis Pengaruh Kepemimpinan, Budaya Organisasi dan Komunikasi Terhadap Kepuasan Kerja Serta Dampaknya Terhadap Kinerja Karyawan
}

Edi Sugiono, Gloria Ida Lumban Tobing

Fakultas Ekonomi dan Bisnis, Universitas Nasional

Jakarta, Indonesias
Research Paper

HR Management

\begin{abstract}
This study analyzes the influence of leadership, organizational culture, and Communication on job satisfaction and its impact on employee performance at PT. Usaha Makalingga Mandiri, Jakarta. The research was conducted using survey methods, samples, and questionnaires as the primary data collection tool, and the subjects were 100 respondents. The method of analysis uses the Structural Equation Model (SEM) for hypothesis testing. The results showed that 1) Leadership, Organizational Culture, and Communication directly positively affect Job Satisfaction. 2) Leadership, Organizational Culture, and Communication positively or indirectly affect employee performance through job satisfaction as a mediating variable. 3) Job Satisfaction partially mediates the influence of Leadership, Organizational Culture, and Communication on Employee Performance. 4) Leadership is the variable with the greatest influence on job satisfaction and employee performance. Increased job satisfaction will have an impact in the form of increased employee performance.
\end{abstract}

\section{Keywords:}

Communication, Employee Performance, Job Satisfaction, Leadership, Organizational Culture

\section{Corresponding Author:}

Edi Sugiono

Fakultas Ekonomi dan Bisnis, Universitas Nasional

Email: edisugiono33@yahoo.com

(c) The Author(s) 2021

DOI: https:// doi.org/ 10.36407/jmsab.v4i2.413
Received: 15 Feb 2021

Accepted: 26 Jul 2021

Online: 29 Jul 2021

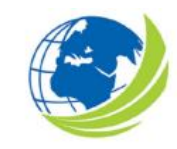

Jurnal Manajemen Strategi dan Aplikasi Bisnis,

Vol 4, No. 2, 2021,

pp. $389-400$

eISSN 2655-237X

\section{(c) (1)}

CC BY: This license allows reusers to distribute, remix, adapt, and build upon the material in any medium or format, so long as attribution is given to the creator. The license allows for commercial use. 


\section{PENDAHULUAN}

Keberhasilan organisasi bukan hanya ditentukan oleh keberhasilan dalam mengelola keuangan tetapi juga ditentukan dari keberhasilannya dalam mengelola sumber daya manusia. Pengelolaan sumber daya yang dimaksud adalah perusahaan harus mampu menyatukan persepsi atau cara pandang karyawan dan pemimpin perusahaan dalam rangka mencapai tujuan perusahaan antara lain melalui pembentukan mental kerja yang baik dengan dedikasi dan loyalitas yang tinggi terhadap pekerjaannya, memberikan bimbingan, pengarahan dan koordinasi yang baik dalam bekerja oleh seorang atasan kepada bawahannya. Selain aspek kepemimpinan dan budaya organisasi, untuk memperkuat kepuasan kerja sangat diperlukan aspek komunikasi dalam organisasi.Komunikasi organisasi memegang peran penting untuk mendukung efektifitas operasional organisasi dimana komunikasi menjadi alat (tool) yang dapat dirancang manajemen untuk pencapaian tujuan organisasi. Manfaat lain dari komunikasi juga dapat dilihat dari fungsi pengendalian (kontrol dan pengawasan), motivasi, pengungkapan emosional dan penyediaan informasi untuk pengambilan keputusan (Robbins, 2001:312).

Pergantian pucuk pimpinan perusahaan dan jajaran manajemen pada tahun 2016, dan budaya organisasi yang berbeda disinyalir menjadi alasan menurunnya kinerja karyawan. Hal ini diketahui dari tingkat kepuasan kerja karyawan terhadap pimpinan, yang dianggap kurang peka dengan apa yang diinginkan karyawan. Hal-hal penting yang disampaikan dari pimpinan harus melalui beberapa tingkatan bagian untuk sampai kepada karyawan sehinggakemungkinan besar sudah terdapat penambahan atau pengurangan informasi karena menyesuaikan dengan tujuan dari pribadi atau divisi tertentu.Karyawan dituntut untuk menyesuaikan diri dalam berkomunikasi dengan situasi dan kondisi yang baru.

Turunnya kinerja karyawan danturnover intention karyawan yang terjadi dalam perusahaan dampak ketidakpuasan di tempat bekerja menjadi hal yang menjadi latar belakang penelitian ini. Hal tersebut data internal yang menyebutkian pencapaian kerja karyawan point kinerja, kompetensi dan pembinaan SDM yang berada dibawah target.Menyikapi turunnya point kompetensi dampak dari keluarnya karyawan-karyawan dengan kemampuan yang telah tersertifikasi, perusahaan terus melakukan pembinaan SDM tetapi hasilnya belum optimal karena untuk mendapatkan karyawan yang memenuhi syarat pekerjaan dilapangan perlu mengikuti training-training yang diadakan oleh lembaga khusus pada waktu tertentu dengan biaya yang cukup mahal dan kondisi karyawan yang tidak siap menerima materi membuat ada karyawan yang tidak lulus training tersebut. Unit-unit kerja yang membutuhkan fleksibilitas tinggi terkadang terbentur dengan lamanya pengambilan keputusan pada tingkat manajemen. Lama pengambilan keputusan yang harus melalui pertemuan-pertemuan berkali-kali sering membuat lepasnya peluang proyek yang ada.

Penelitian yang dilakukan (Brury, 2016) menemukan bahwa kepuasaan dan ketidakpuasaan yang dirasakan pegawai dalam melaksanakan tugas merupakan hal yang senantiasa selalu ada dalam suatu organisasi.Hasil penelitian menyatakan bahwa variabel kepemimpinan, budaya organisasi, motivasi kerja dan kepuasan kerja berpengaruh terhadap kinerja Pegawai pada Kantor SAR Sorong bersifat signifikan. Penelitian (Poerwaningrum \& Sudirjo, 2016) mendukung hal sama pada pengaruh kepemimpinan, budaya organisasi dan kepuasan kerja yang berpengaruh poisitif dan signifikan terhadap kinerja karyawan. Penelitian lain (Nabi et al., 2017) menyatakan bahwa komunikasi yang efektif memiliki pengaruh yang tak terbantahkan dan jelas pada kinerja karyawan dan kepuasan secara keseluruhan. Hal serupa turut dikemukakan oleh (Alhassan et al., 2017)yang mengungkapkan bahwa ada korelasi yang kuat 


\section{Edi Sugiono \& Gloria Ida Lumban Tobing}

Communication, employee performance...

antara komunikasi dengan kepuasan kerja, dan memberikan sorotan pentingnya komunikasi yang efektif dalam membantu kepuasan kerja karyawan selain meningkatkan kinerja. Dari penelitianpenelitian terdahulu bisa disimpulkan bahwa kepuasan kerja dipengaruhi secara positif oleh kepemimpinan, budaya organisasi dan komunikasi serta memberikan dampak terhadap kinerja karyawan.

Tetapi tidak semua penelitian terdahulu memberikan hasil yang sama. Kesenjangan penelitian(gap research) disampaikan oleh (Hidayat, 2013)yang menyatakan bahwa kepemimpinan tidak berpengaruh positif dan signifikan terhadap kepuasan kerja, (Brahmasi \& Suprayetno, 2008). Budaya organisasi tidak berpengaruh signifikan terhadap kepuasan kerja (Sadiartha \& Sitorus, 2018). Pengaruh budaya organisasi tidak signifikan dan positif terhadap kinerja karyawan (Pawirosumarto et al., 2017) Komunikasi tidak memberikan pengaruh yang positif dan signifikan terhadap kepuasan kerja, (Riyadi et al., 2017) dan penelitian lainnya (Abidin, 2010) menyatakan bahwa kepuasan kerja tidak berpengaruh signifikan terhadap kinerja pegawai. Adanya kesenjangan penelitian (gap research)menjadi latar belakang peneliti menggunakan beberapa jurnal tersebut sebagai alasan penelitian dan memasukan kepuasan kerja sebagai variabel mediasi terhadap kepemimpinan, budaya organisasi, komunikasi,dan kinerja karyawan.

Adapun untuk bidang pekerjaan tempat penelitian-penelitian sebelumnya berbeda dengan bidang kerja penelitian ini, sekalipun bergerak dalam bidang jasa tetapi karena produk yang dihasilkan adalah barang yang sangat berbahaya sehingga ada tata cara khusus dan peraturan-peraturan penanganan yang harus dipatuhi dan tidak dapat diabaikan. Penggunaan beberapa variabel penelitian yang serupa menjadi alasan peneliti memasukkan beberapa jurnal lainnya sebagai rujukan.Berdasarkan latar belakang di atas, maka penelitian dilakukan untuk menganalisi pengaruh kepemimpinan, budaya organisasi dan komunikasi terhadap kinerja karyawan yang dimediasi oleh kepuasan kerja di PT. UMM.

Tujuan pertama penelitian adalah untuk mengetahui hubungan dan pengaruh kepemimpinan, budaya organisasi dan komunikasi terhadap kepuasan kerja (Brury, 2016), (Ardiansyah, 2016). Tujuan kedua adalah untuk mengetahui hubungan dan pengaruh kepemimpinan, budaya organisasi, komunikasi dan kepuasan kerja terhadap kinerja karyawan (Ardiansyah, 2016; Brury, 2016; Poerwaningrum \& Sudirjo, 2016). Penelitian ini diharapkan juga dapat berkontribusi menutupi gap research dari penelitian sebelumnya.

\section{KAJIAN PUSTAKA}

\section{Kepemimpinan, Kepuasan Kerja, Kinerja Karyawan.}

Kepemimpinan dinyatakan sebagai "proses untuk mempengaruhi orang lain untuk memahami dan setuju dengan apa yang perlu dilakukan dan bagaimana tugas itu dilakukan secara efektif, serta proses untuk memfasilitasi upaya individu dan kolektif untuk mencapai tujuan bersama", (Yukl, 2012). Fungsi kepemimpinan berhubungan langsung dengan situasi sosial dan kehidupan kelompok atau organisasi masing-masing, yang mengisyaratkan bahwa setiap pemimpin berada didalam dan bukan berada disituasi itu. Fungsi kepemimpinan merupakan gejala sosial, karena harus diwujudkan dalam interaksi antar individu didalam situasi sosial suatu kelompok atau organisasi (Veithzal, 2008).

Proses kepemimpinan akan berlangsung efektif bilamana pemimpin memiliki kepribadian yang baik dan menunjang kemajuan organisasi. Hal ini sesuai dengan pernyataan (Rivai \& Mulyadi, 2012).Teori ini didukung oleh penelitian Chang dan Lee (2007) dan Brury (2016) menyatakan bahwa kepemimpinan berpengaruh positif dan signifikan terhadap kepuasan kerja. Studi lainnya (Poerwaningrum \& Sudirjo, 2016) menyatakan bahwa 
Jurnal Manajemen Strategi dan Aplikasi Bisnis, Volume 4, Nomor. 2, 2021. 389 - 400

kepemimpinan berpengaruh terhadap kinerja karyawan. Berdasarkan teori dan penelitian terdahuli, maka dirumuskan hipotesis sebagai berikut :

H1 : $\quad$ Kepemimpinan secara langsung berpengaruh positif dan signifikan terhadap Kepuasan Kerja.

H4 : $\quad$ Kepemimpinan secara langsung berpengaruh positif dan signifikan terhadap Kinerja Karyawan.

H8: Kepemimpinan secara tidak langsung berpengaruh positif dan signifikan terhadap Kinerja Karyawan melalui Kepuasan Kerja.

\section{Budaya Organisasi, Kepuasan Kerja, Kinerja Karyawan.}

Amnuai dalam (Tika, 2006) mendefinisikan "budaya organisasi sebagai seperangkat asumsi dasar dan keyakinan yang dianut oleh anggota-anggota organisasi, kemudian dikembangkan dan diwariskan guna mengatasi masalah-masalah adaptasi ekternal dan masalah integrasi internal". Edgar Schein dalam Luthans (2006:124) menyatakan bahwa "budaya organisasi adalah pola asumsi dasar diciptakan, ditemukan atau dikembangkan oleh kelompok tertentu saat mereka menyesuaikan diri dengan masalah-masalah eksternal dan internal yang telah bekerja cukup baik serta dianggap berharga dan karena itu diajarkan pada anggota baru sebagai cara yang benar untuk menyadari, berpikir dan merasakan hubungan dengan masalah tersebut". Menurut Kreitner dan Kinicki (2005: 79) membagi empat fungsi budaya organisasi yaitu : a). Memberikan identitas organisasi kepada karyawannya. b). Memudahkan komitmen kolektif. c).Mempromosikan stabilitas sistem sosial. d).Membentuk perilaku dengan membantu manajer merasakan keberadaannya.Teori ini didukung oleh penelitian (Widyawatiningrum et al., 2015), (Chang \& Lee, 2007) yang menyatakan bahwa budaya organisasi berpengaruh positif terhadap kepuasan kerja. Berdasarkan teori dan penelitian terdahulu, maka dirumuskan hipotesis sebagai berikut :

H2 : Budaya Organisasi secara langsung berpengaruh positif dan signifikan terhadap Kepuasan Kerja.

H5 : Budaya Organisasi secara langsung berpengaruh positif dan signifikan terhadap Kinerja Karyawan.

H9 : Budaya Organisasi secara tidak langsung berpengaruh positif dan signifikan terhadap Kinerja Karyawan melalui Kepuasan kerja.

\section{Komunikasi, Kepuasan Kerja, Kinerja Karyawan}

Gibson dan Ivan (2012: 84) mengemukakan bahwa "komunikasi adalah pengiriman informasi dan pemahaman mengenai simbol verbal dan non verbal". Komunikasi adalah "proses pemindahan pengertian dalam bentuk gagasan atau informasi dari seseorang ke orang lain.Untuk mencapai tujuan organisasi maka diperlukan komunikasi yang baik, dimana terdapat jalinan pengertian dalam komunikasi tersebut sehingga dapat dimengerti serta dapat dilaksanakan antara pihak yang satu dengan pihak yang lain". (Robbins, 2013) menyebutkan bahwa komunikasi membantu perkembangan motivasi dengan menjelaskan kepada para karyawan apa yang harus dilakukan, seberapa baik mereka bekerja, dan apa yang dapat dikerjakan untuk memperbaiki kinerja yang dibawah standar. Teori ini didukung oleh peneiitian sebelumnya (Alhassan et al., 2017; Gede Sadiartha \& Sitorus, 2018) yang 


\section{Edi Sugiono \& Gloria Ida Lumban Tobing}

Communication, employee performance...

menyatakan bahwa komunikasi memberikan pengaruh positif terhadap kepuasan kerja. Berdasarkan teori dan penelitian terdahulu, maka dirumuskan hipotesis sebagai berikut:

H3 : Komunikasi secara langsung berpengaruh positif dan signifikan terhadap Kepuasan Kerja.

H6 : Komunikasi secara langsung berpengaruh positif dan signifikan terhadap Kinerja Karyawan.

H10 : Komunikasi secara tidak langsung berpengaruh positif dan signifikan terhadap Kinerja Karyawan melalui Kepuasan kerja.

\section{Kepuasan Kerja, Kinerja Karyawan}

Sedangkan menurut (Veithzal, 2008, p. 249), kepuasan kerja adalah "penilaian dari pekerja tentang seberapa jauh pekerjaannya secara keseluruhan memuaskan kebutuhannya. Kepuasan kerja juga adalah sikap umum yang merupakan hasil dari beberapa sikap khusus terhadap faktor-faktor pekerjaan, penyesuaian diri dan hubungan sosial individu di luar kerja". Dapat dinyatakan bahwa seorang pegawai dengan kepuasan kerja yang tinggi akan lebih memiliki perasaan positif dibandingkan karyawan yang memiliki tingkat kepuasan rendah (Robbins and Judge, 2008 : 99).Teori ini didukung oleh penelitian (Sugiono \& Vitaloka, 2019) yang menyatakan bahwa kepuasan kerja berpengaruh positif dan signifikan terhadap kinerja karyawan. Berdasarkan teori dan penelitian terdahulu, maka dirumuskan hipotesis sebagai berikut:

H7 : $\quad$ Kepuasan Kerja secara langsung berpengaruh positif dan signifikan terhadap Kinerja Karyawan.

\section{METODE}

\section{Populasi dan Sampel}

Penelitian ini menggunakan seluruh anggota populasinya yang meliputi semua karyawan PT. Usaha Makalingga Mandiri yang berjumlah 100 orang. Menurut (Hair et al., 2010) yang dikutip oleh Ferdinand (2002) menyatakan bahwa ukuran sampel (data observasi) yang sesuai adalah antara 100-200, sampel yang dianalisis sebagai input adalah 100 responden. Sehingga penggunaan 100 responden dianggap memenuhi syarat untuk penelitian dan memenuhi syarat penelitian dengan Structural Equation Model (SEM). Responden terdiri dari 57 laki-laki (57\%) dan 43 wanita (43\%). Sebanyak 42\% berusia antara 31-40 tahun. Mayoritas responden berpendidikan S1 (49\%) dan 48\% responden memiliki masa kerja lebih dari 11 tahun.

\section{Metode Pengukuran Data}

Untuk mengukur hasil tanggapan responden, maka digunakan Skala Likert, dimana jawaban yang mendukung pertanyaan diberikan skor yang tinggi sedangkan jawaban yang tidak atau kurang mendukung diberi skor rendah. Kinnear (1998) dalam Husein Umar (2003 : 137), menyatakan dalam menggunakan skala Likert, data yang berhasil dikumpulkan dari kuesioner selanjutnya akan diukur dengan hitung 1 sampai 5, dengan kategori : a) Sangat Setuju = 5. b) Setuju = 4. c) Cukup Setuju =3. d) Tidak Setuju =2. e) Sangat Tidak Setuju $=1$.

\section{Metode Analisis}

Uji instrumen penelitian menggunakan SPSS 23 pada uji validitas dan uji reabilitas. Uji hipotesis menggunakan Structural Equation Modeling (SEM). Pengaruh tidak langsung melalui mediasi variabel kepuasan kerja menggunakan Uji Sobel. (Ghozali, 2011). MetodeVariance Account For 
(VAF) diuji untuk mengetahui nilai kontribusi variabel mediator.

\section{HASIL DAN PEMBAHASAN}

\section{Analisa Deskriptif}

Hasil analisa deskriptif menunjukkan skor rata-rata untuk Kepemimpinan sebesar 3,68, Budaya Organisasi sebesar 3,56, Komunikasi sebesar 3,68, Kepuasan Kerja sebesar 3,70 dan Kinerja Karyawan sebesar 3,83.

\section{Instrumen Penelitian}

Uji validitas dan reabilitas dengan menggunakan uji Korelasi Product Moment Pearson dan Cronbach's Alpha,mengacu pada pendapat Notoatmojo (1993) yang menyatakan bahwa melakukan kedua uji tersebut dengan tujuan untuk mengetahui kesahihan dan konsistensi jawaban responden terhadap seluruh item pertanyaan pada masing-masing indikator yang diberikan.Analisis penelitian dilakukan dengan mengkorelasikan masing-masing skor item dengan skor total. Hasil penelitian menyatakan bahwa nilai $r$ hitung yakni corrected item total correlation masing-masing butir pertanyaan menunjukkan nilai $r$ hitung yang lebih besar dari $r$ tabel, maka butir pertanyaan atau indikator yang digunakan dalam penelitian dinyatakan valid (Ghozali, 2011). Dari hasil pengujian reliabilitas pada variabel Kepemimpinan, Budaya Organisasi, Komunikasi, Kepuasan kerja dan Kinerja Karyawan didapat nilai Alpha Cronbach di atas 0,70 dengan demikian instrumen penelitian dinyatakan reliabel.

\section{Hasil Analisis Model SEM}

Hasil uji terhadap kesesuaian model SEM (goodness of fit) ditampilkan pada Tabel di bawah ini:

\section{Tabel 1.}

Hasil Uji Kesesuaian Model

\begin{tabular}{lccc}
\hline \multicolumn{1}{c}{ Goodness of Fit Index } & Cut off Value & Hasil Estimasi & $\begin{array}{l}\text { Evaluasi } \\
\text { Model }\end{array}$ \\
\hline Chi-Square $(\mathrm{df}=1315)$ & Kecil $(\varangle 00,47)$ & 1841 & Kurang Baik \\
Probability & $\geq 0,05$ & 0 & Kurang Baik \\
CMIN/DF & $\leq 2,00$ & 1.4 & Baik \\
RMSEA & $\leq 0,08$ & 0.064 & Baik \\
TLI & $\geq 0,95$ & 0.8 & Marjinal \\
CFI & $\geq 0,95$ & 0.809 & Marjinal \\
GFI & $\geq 0,90$ & 0.636 & Kurang Baik \\
AGFI & $\geq 0,90$ & 0.604 & Kurang Baik \\
\hline
\end{tabular}

Sumber: diolah dengan AMOS 20

Berdasarkan hasil pengujian kelayakan model konfirmatori kelima variabel, baik eksogen dan endogen diketahui bahwa kriteria chi square, probabilitas, GFI dan AGFI termasuk pada kategori kurang baik (non fit). Nilai hasil estimasi Chi square 1841,00>00,47 sehingga termasuk pada kategori kurang baik (non fit). Nilai hasil estimasi Probability $0,000<0,05$ sehingga termasuk pada kategori kurang baik (non fit). Nilai hasil estimasi GFI sebesar 0,636 <0,90 sehingga 


\section{Edi Sugiono \& Gloria Ida Lumban Tobing}

Communication, employee performance...

termasuk pada kategori kurang baik (non fit). Nilai hasil estimasi AGFI sebesar 0,604 <0,90 sehingga termasuk pada kategori kurang baik (non fit). Namun, untuk nilai hasil estimasi CMIN/ DF sebesar 1,400 $\leq 2,00$ sehingga termasuk pada kategori baik (good fit). Nilai hasil estimasi RMSEA sebesar 0,064 $\leq 0,08$ sehingga termasuk pada kategori baik (good fit). Sementara nilai hasil estimasi TLI sebesar 0,800 $<0,95$ sehingga termasuk pada kategori cukup baik (marginal). Nilai hasil estimai CFI sebesar 0,809 <0,95 sehingga termasuk pada kategori cukup baik (marginal). Seperti dijelaskan oleh Solimun dalam Aryani dan Rosinta (2010), jika ada satu atau lebih parameter yang telah fit maka model dinyatakan fit. Dengan demikian dapat disimpulkan bahwa kecocokan model yang diprediksi dengan nilai-nilai pengamatan sudah memenuhi syarat, maka analisis dapat dilanjutkan pada pengujian hipotesis. Hal ini didukung oleh hasil penelitian (Fitriyana, dkk, 2013) yang menyatakan bahwa nilai marginal adalah kondisi kesesuaian model pengukuran di bawah kriteria ukuran absolute fit maupun incremental fit, namun masih dapat diteruskan pada analisis lebih lanjut karena dekat dengan kriteria good fit.

\section{Pengujian Hipotesis Dircet Effect}

Nilai estimasi koefisien jalur diketahui pada Standardized Regression Weights, nilai signifikansi pengaruhnya diketahui dari nilai CR (Critical Ratio) atau nilai probabilitas (p). Berdasarkan hasil analisis SEM dapat diketahui bahwa Kepemimpinan berpengaruh positif dan signifikan terhadap Kepuasan Kerja . Hal ini dibuktikan dari nilai critical ratio (CR) sebesar 2,813 > 1,96 dengan probabilitas sebesar $0,005<0,05$. Sehingga hipotesis pertama yang menyatakan bahwa Kepemimpinan secara langsung berpengaruh positif dan signifikan terhadap Kepuasan Kerja, diterima.Adapun penelitian ini konsisten dengan penelitian (Diatmika Paripurna, 2013) yang menyatakan bahwa variabel kepemimpinan menjadi variabel yang berpengaruh paling dominan terhadap kepuasan kerja karyawan, selain variabel lingkungan kerja dan komunikasi.

Tabel 2.

Regression Weights:

\begin{tabular}{lllccccc}
\hline & & & Estimate & \multicolumn{1}{c}{ S.E. } & C.R. & P & Label \\
\hline Kepuasan_Kerja & $<--$ & Kepemimpinan &, 535 &, 190 & 2,813 &, 005 & par_48 \\
Kepuasan_Kerja & $<--$ & Budaya_Organisasi &, 250 &, 093 & 2,691 &, 007 & par_50 \\
Kepuasan_Kerja & $\leftarrow--$ & Komunikasi &, 276 &, 098 & 2,819 &, 005 & par_51 \\
Kinerja_Karyawan & $<--$ & Kepemimpinan &, 301 &, 151 & 1,989 &, 047 & par_49 \\
Kinerja_Karyawan & $<--$ & Budaya_Organisasi &, 153 &, 074 & 2,075 &, 038 & par_52 \\
Kinerja_Karyawan & $<--$ & Komunikasi &, 156 &, 078 & 2,007 &, 045 & par_53 \\
Kinerja Karyawan & $\leftarrow--$ & Kepuasan_Kerja &, 397 &, 132 & 3,008 &, 003 & par_54 \\
\hline
\end{tabular}

Sumber: diolah dengan AMOS 20

Kedua, budaya organisasi berpengaruh positif dan signifikan terhadap Kepuasan Kerja. Hal tersebut menyatakan bahwa jika terjadi peningkatan pada budaya organisasi, maka akan berdampak juga pada peningkatan kepuasan kerja, sehingga hipotesis kedua yang menyatakan bahwa Budaya Organisasi secara langsung berpengaruh positif dan signifikan terhadap Kepuasan Kerja, diterima. Hal ini konsiten dengan penelitian terdahulu (Widyawatiningrum dkk., 2015) yang menyatakan bahwa budaya organisasi berpengaruh signifikan terhadap kepuasan kerja.

Ketiga, hasil analisis SEM dapat diketahui bahwa Komunikasi berpengaruh positif dan signifikan terhadap Kepuasan Kerja. Hal ini konsisten dengan penelitian (Dahliawati, 2015) yang menyatakan bahwa ada korelasi yang signifikan antara komunikasi organisasi dengan kepuasan kerja karyawan. Hasil penelitian yang mendukung lainnya dikemukakan oleh (Alhassan dkk., 2017) menyatakan bahwa ada korelasi yang kuat antara komunikasi dengan kepuasan kerja. 
Jurnal Manajemen Strategi dan Aplikasi Bisnis, Volume 4, Nomor. 2, 2021. 389 - 400

Namun hasil penelitian ini bertolak belakang dengan penelitian (Riyadi dkk., 2017) yang menyatakan bahwa komunikasi tidak memberikan pengaruh yang positif dan signifikan terhadap kepuasan kerja.

Ke-empat, kepemimpinan berpengaruh positif dan signifikan terhadap Kinerja Karyawan. Hal ini menunjukkan bahwa adanya peningkatan pada kepemimpinan akan berdampak pada peningkatan kinerja karyawan, sehingga hipotesis keempat yang menyatakan bahwa Kepemimpinan secara langsung berpengaruh positif dan signifikan terhadap Kinerja Karyawan, diterima. Hal ini konsisten dengan penelitian sebelumnya oleh (Brury, 2016) dan (Widyawatiningrum dkk, 2015) yang menyatakan bahwa kepemimpinan mempunyai pengaruh positif dan signifikan terhadap kinerja karyawan.

Kelima, budaya Organisasi berpengaruh positif dan signifikan terhadap Kinerja Karyawan. Hal ini menunjukkan bahwa jika budaya organisasi mengalami peningkatan, maka akan berdampak pada peningkatan kinerja karyawan, sehingga hipotesis kelima yang menyatakan bahwa Budaya Organisasi secara langsung berpengaruh positif dan signifikan terhadap Kinerja Karyawan, diterima. Hasil penelitian yang sama dan mendukung hal tersebut juga telah dilakukan oleh (Shahzad, 2014) yang menyatakan bahwa budaya organisasi yang kuat akan meningkatkan kinerja karyawan dan penelitian (Widyawatiningrum dkk, 2015) yang menyatakan bahwa budaya organisasi berpengaruh signifikan terhadap kinerja karyawan. Penelitian ini berbeda dengan hasil penelitian (Pawirosumarto dkk, 2017) yang menyatakan bahwa budaya organisasi tidak memiliki pengaruh yang signifikan dan positif terhadap kinerja karyawan di Parador Hotels and Resorts.

Ke-enam, komunikasi berpengaruh positif dan signifikan terhadap Kinerja Karyawan. Dengan demikian, jika terjadi peningkatan pada komunikasi, maka akan berdampak pada peningkatan kinerja karyawan, sehingga hipotesis keenam yang menyatakan bahwa Komunikasi secara langsung berpengaruh positif dan signifikan terhadap Kinerja Karyawan, diterima. Hal ini didukung oleh hasil penelitian (Afianto \& Utami, 2017) yang menyatakan bahwa komunikasi organisasi berpengaruh signifikan positif terhadap kepuasan kerja. Hasil penelitian ini didukung oleh penelitian (Semegine, 2012) yang menyatakan bahwa proses komunikasi berperan dalam memelihara dan mengembangkan manajemen organisasi yang efisien, dimana peningkatan efisiensi dalam kinerja karyawan berarti penghematan dan menghasilkan keuntungan. Kinerja karyawan yang meningkat tentunya akan berdampak pula pada kesuksesan perusahaan dalam mencapai target dan tujuannya.

Ketujuh, kepuasan Kerja berpengaruh positif dan signifikan terhadap Kinerja Karyawan. Jika terjadi peningkatan pada kepuasan kerja karyawan, maka akan berdampak pula pada peningkatan kinerja karyawan, sehingga hipotesis ketujuh yang menyatakan bahwa Kepuasan Kerja secara langsung berpengaruh positif dan signifikan terhadap Kinerja Karyawan, diterima. Hal ini konsisten dengan penelitian (Brury, 2016) dan (E. Sugiono \& Vitaloka, 2019) yang menyatakan bahwa kepuasan kerja mempunyai pengaruh positif dan signifikan terhadap kinerja karyawan. Hasil penelitian ini bertolak belakang dengan penelitian (Pawirosumarto dkk., 2017) yang menyatakan bahwa kepuasan kerja tidak mempengaruhi kinerja karyawan di Parador Hotels and Resorts secara signifikan dan positif.

\section{Pengujian Hipotesis Indircet Effect}

Berdasarkan hasil analisis uji Sobel (Sobel Test) dapat diketahui bahwa Kepemimpinan berpengaruh positif dan signifikan terhadap Kinerja Karyawan melalui Kepuasan Kerja. Hal ini 


\section{Edi Sugiono \& Gloria Ida Lumban Tobing}

Communication, employee performance...

dibuktikan dari nilai CR sebesar 2,054 dengan probabilitas sebesar 0,039. Oleh karena nilai CR > 1,96 dan probabilitas < 0,05, maka dapat disimpulkan bahwa Kepuasan Kerja memediasi berpengaruh Kepemimpinan terhadap Kinerja Karyawan. Hal ini menunjukkan bahwa jika terjadi peningkatan pada kepemimpinan melalui kepuasan kerja, maka akan berdampak juga pada peningkatan kinerja karyawan, sehingga hipotesis kedelapan yang menyatakan bahwa Kepemimpinan secara tidak langsung berpengaruh positif dan signifikan terhadap Kinerja Karyawan melalui Kepuasan Kerja, diterima. Penelitian serupa didukung oleh (Rokib, M.N \& D. Santoso, 2017) menyatakan bahwa hasil analisis jalur pada variabel gaya kepemimpinan partisipatif dan komunikasi organisasi dapat berpengaruh langsung maupun tidak langsung dengan dimediasi kepuasan kerja sebagai variabel intervening terhadap kinerja karyawan pada KJPP Jimmy Prasetyo \& Rekan.

Budaya Organisasi juga berpengaruh positif dan signifikan terkadap Kinerja Karyawan melalui Kepuasan Kerja. Hal ini dibuktikan dari nilai CR sebesar 2,005 dengan probabilitas sebesar 0,044. Oleh karena nilai CR $>1,96$ dan probabilitas $<0,05$, maka dapat disimpulkan bahwa Kepuasan Kerja memediasi berpengaruh Budaya Organisasi terhadap Kinerja Karyawan, sehingga hipotesis kesembilan yang menyatakan bahwa Budaya Organisasi secara tidak langsung berpengaruh positif dan signifikan terhadap Kinerja Karyawan melalui Kepuasan Kerja, diterima. Hal ini konsisten dengan penelitian (Baskoro dkk, 2013) yang menyatakan bahwa budaya organisasi berpengaruh terhadap kinerja karyawan melalui kepuasan kerja.Hal berbeda disampaikan dalam hasil penelitian (Mira, 2017) yang menyatakan bahwa kepuasan kerja tidak memiliki kemampuan dalam memediasi budaya organisasi terhadap kinerja karyawan PT. Jasa Raharja (Persero) Cabang Bali. Hal ini memberikan dua indikasi yaitu :1) kepuasan karyawan telah terpenuhi sehingga karyawan memiliki motivasi yang lebih kuat untuk berprestasi dalam pekerjaannya daripada imbalan melalui melalui kepuasan kerja atau 2) kepuasan karyawan tidak sesuai dengan yang diharapkan, sehingga budaya organisasi memiliki pengaruh langsung yang lebih kuat terhadap kinerja karyawan daripada pengaruh tidak langsung melalui kepuasan karyawan.

Berdasarkan hasil analisis uji Sobel (Sobel Test) dapat diketahui bahwa Komunikasi berpengaruh positif dan signifikan terkadap Kinerja Karyawan melalui Kepuasan Kerja. Hal ini dibuktikan dari nilai $\mathrm{CR}$ sebesar 2,056 dengan probabilitas sebesar 0,039. Oleh karena nilai CR > 1,96 dan probabilitas < 0,05, maka dapat disimpulkan bahwa Kepuasan Kerja memediasi berpengaruh Komunikasi terhadap Kinerja Karyawan. Hal ini menunjukkan bahwa jika ada peningkatan pada komunikasi melalui kepuasan kerja, maka akan berdampak juga pada peningkatan kinerja karyawan, sehingga hipotesis kesepuluh yang menyatakan bahwa Komunikasi secara tidak langsung berpengaruh positif dan signifikan terhadap Kinerja Karyawan melalui Kepuasan Kerja, diterima.Hal ini konsisten dengan penelitian sebelumnya oleh (Ardiansyah, 2016) yang menyatakan bahwa kepuasan kerja menjadi mediator positif pada komunikasi terhadap kinerja karyawan.

\section{KESIMPULAN DAN IMPLIKASI}

Pengaruh kepemimpinan yang baik mampu memberikan dampak positif secara langsung terhadap kepuasan kerja, yang artinya hasil pelaksanaan aktivitas manajerial kepemimpinan yang dilaksanakan akan selalu menghasilkan peningkatan pada kepuasan kerja karyawan di PT. UMM. Pengaruh tidak langsung kepemimpinan terhadap kinerja karyawan melalui kepuasan kerja juga menunjukkan hasil yang positif. Namun hasil penelitian menunjukkan bahwa pengaruh langsung kepemimpinan terhadap kinerja karyawan lebih besar daripada pengaruh tidak langsung, sehingga peningkatan pelaksanaan manajerial yang dilakukan melalui kepuasan kerja tidak memberikan dampak yang lebih besar jika dibandingkan dengan hasil pelaksanaan manajerial 
Jurnal Manajemen Strategi dan Aplikasi Bisnis, Volume 4, Nomor. 2, 2021. 389 - 400

yang langsung terhadap kinerja karyawan. Maka diperlukan adanya pengaruh lain yang mendukung upaya kepemimpinan terhadap kepuasan kerja sehingga berdampak terhadap kinerja karyawan di PT. UMM.

Pengaruh budaya organisasi yang konsisten dilaksanakan mampu meningkatkan kepuasan kerja yang artinya semakin meningkat budaya organisasi dalam perusahan maka kepuasan kerja karyawan akan semakin meningkat. Seberapa jauh perusahaan bersedia mempertimbangkan faktor manusia didalam pengambilan keputusan manajemen akan meningkatkan kepuasan kerja karyawan di PT. UMM. Pengaruh budaya organisasi terhadap kinerja karyawan melalui kepuasan kerja juga menunjukkan hasil yang positif.Namun hasil penelitian ini menunjukkan bahwa pengaruh langsung budaya organisasi lebih besar daripada pengaruh tidak langsung melalui kepuasan kerja, sehingga penerapan budaya organisasi yang dilakukan melalui kepuasan kerja tidak memberikan dampak yang lebih besar terhadap kinerja karyawan dibandingkan dengan dampak penerapan budaya organisasi secara langsung terhadap kinerja karyawan. Maka diperlukan pengaruh lain dalam rangka peningkatan budaya organisasi terhadap kepuasan kerja agar berdampak juga pada peningkatan kinerja karyawan di PT. Usaha Makalingga Mandiri.

Pengaruh komunikasi yang harmonis dalam perusahaan mampu meningkatkan kepuasan kerja. Hal ini menunjukkan jika komunikasi dalam perusahaan mengalami peningkatan dan perbaikan maka akan berdampak pada peningkatan pada kepuasan kerja karyawan. Perbaikan saluran informasi baik informal maupun informal yang berkesinambungan diharapkan dapat meningkatkan kepuasan kerja karyawan di PT. UMM. Pengaruh komunikasi terhadap kinerja karyawan melalui kepuasan kerja juga menunjukkan hasil yang positif.Namun pengaruh langsung komunikasi terhadap kinerja karyawan lebih besar daripada pengaruh tidak langsung. Sehingga diperlukan adanya pengaruh lain dalam peningkatkan kegiatan komunikasi secara langsung untuk membantu meningkatkan kepuasan kerja sehingga berdampak peningkatan juga pada kinerja karyawan. Hal ini dapat dilakukan dengan sosialisasi langsung informasi mengenai aturan dan kebijakan perusahaan serta kepastian informasi mengenai pengangkatan atau kesempatan pengembangan karyawan di PT. UMM.

Pengaruh kepuasan kerja yang meningkat akan memberikan dampak langsung berupa peningkatan terhadap kinerja karyawan. Hal ini dapat dilakukan dengan lebih memberikan penghargaan atas prestasi kerja karyawan, dukungan dalam pemecahan masalah dalam pekerjaan dan melibatkan karyawan dalam menetapkan keputusan perusahaan yang membawa kabaikan bagi manajemen perusahaan dan karyawan.Perusahaan perlu melakukan evaluasi terhadap sistem pemberian kompensasi insentif dan bonus yang sesuai dengan peraturan dan pencapaian target kerja. Jika selama ini perusahaan telah mengacu pada Undang-Undang Tenaga kerja dalam memberikan kompensasi, dan cukup baik maka untuk kedepan diharapkan adanya transparansi mengenai tolak ukur yang jelas dalam penentuan besaran kenaikan kompensasi karyawan, sehingga memenuhi rasa keadilan pada karyawan di PT. UMM.

\section{Keterbatasan dan Saran}

Terdapat sejumlah keterbatasan dalam penelitian ini.Hal itu adalah masalah jawaban hasil kuesioner yang sebagian besar menjawab Setuju (4) sementara hal tersebut berbeda dengan kondisi di lapangan.Kecenderungan responden dengan pilihan tersebut disinyalir untuk menghindar dari hal-hal lain yang dianggap dapat merugikan pihak karyawan itu sendiri.

\section{REFERENSI}




\section{Edi Sugiono \& Gloria Ida Lumban Tobing}

Communication, employee performance...

Abidin, N. (2010). Pengaruh kepuasan, motivasi dan kedisiplinan kerja terhadap kinerja pegawai di lingkungan kantor wilayah departemen agama provinsi jawa tengah. Program Pasca Sarjana Universitas Dian Nuswantoro Semarang, 38.

Afianto, I. D., \& Utami, H. N. (2017). Pengaruh Disiplin Kerja dan Komunikasi Organisasi Terhadap Kepuasan Kerja Dan Kinerja Karyawan. (Studi pada Karyawan Divisi Marketing PT. Victory International Futures Kota Malang). Jurnal Administrasi Bisnis S1 Universitas Brawijaya, 50(6), 58-67. Diakses tanggal 4 Agustu 2020.

Alhassan, M. A., Ghazali, Z., \& Ahmad, N. S. I. (2017). Relationship between Organizational Communication and Job Satisfaction in Temporary Work Environment: An Empirical Study of Plant Turnaround Workers. Global Business \& Management Research:An International Journal, 9(1), 73-84.

Ardiansyah, D. O. (2016). Pengaruh Komunikasi Terhadap Kinerja Karyawan Dengan Dimediasi Oleh Kepuasan Ker/Ja. Jurnal Bisnis Dan Manajemen. https:/ / doi.org/ 10.13140/ RG.2.1.5183.7283

Baskoro, B., Hidayat, W., \&Waluyo, H. (2013). Pengaruh Budaya Organisasi, Motivasi, Melalui Kepuasan Kerja Terhadap Kinerja Karyawan Pada Pt. Janur Kuning Kudus. Jurnal Ilmu Administrasi Bisnis, 2(3), 182191.https:/ / ejournal3.undip.ac.id/index.php/jiab/ article/ view/3106

Belias, D and Koustelios, A, (2014), Organizational Culture and Job Satisfaction: A Review. Journal of Management and Marketing, 4, 132149.https:// www.econjournals.com/ index.php/irmm/ article/view/ 746.

Bratanata, M., Hamid, N., \& Y, R. M. (2016). Analisis Kinerja Mine Operation dengan Pendekatan Analisa Key Performance Indicator dan Analisa Balanced Scorecard.Neliti.Com,112.

Brury, M. (2016). Pengaruh Kepemimpinan, Budaya Organisasi, Motivasi Kerja Dan Kepuasan Kerja Terhadap Kinerja Pegawai Pada Kantor SAR Sorong. Jurnal Riset Bisnis Dan Manajemen, 4(1), 1-16.

Chang, S. C., \& Lee, M. S. (2007). A study on relationship among leadership, organizational culture, the operation of learning organization and employees' job satisfaction. Learning Organization, 14(2), 155-185. https:/ / doi.org/ 10.1108/ 09696470710727014

Gede Sadiartha, A. A. N., \& Sitorus, S. A. (2018). Organizational Culture, Communication and Leadership Style on Job Satisfaction. International Journal of Research in Business and Social Science (2147-4478), 7(4), 01. https:/ / doi.org/ 10.20525/ijrbs.v7i4.889

Hair, J. F., Black, W. C., Babin, B. J., \& Anderson, R. E. (2010). Multivariate Data Analysis. In Vectors. https:// doi.org/ 10.1016/j.ijpharm.2011.02.019

Hidayat, R. (2013). Pengaruh Kepemimpinan terhadap Komunikasi , Kepuasan Kerja , dan Komitmen Organisasi pada Industri Perbankan. Makara Seri Sosial Humaniora, 17(1), 19-32. https:// doi.org/ 10.7454/ mssh.v17i1.

Mira, H. (2017). Peranan Kepuasan Karyawan Dalam Memediasi Budaya Organisasi Terhadap Kinerja Karyawan (Studi Kasus Pada PT. JasaRaharja (Persero) Cabang Bali). 3(1), 3953.https:/ / www.neliti.com/ publications/ 135565/ peranan-kepuasan-karyawan-dalammemediasi-budaya-organisasi-terhadap-kinerja-kar

Muhammad Nur Rokib \& D. Santoso, Pengaruh Gaya Kepemimpinan Partisipatif Dan Komunikasi Organisasi Terhadap Kinerja Karyawan Melalui Kepuasan Kerja Sebagai Variabel Intervening, ISSN 1979-4800 (cetak)25808451(onlinehttps:/ / www.researchgate.net/ publication/ 329622787 PENGARUH GAYA KEP EMIMPINAN_PARTISIPATIF_DAN_KOMUNIKASI_ORGANISASI TERHĀDAP_KINERJA_KA $\bar{R} Y A$ WAN MELALUI KEPUASAN_KERJA SEBAGAI VARIABEL INTERVENING.

Nabi, N. M., Foysol, K. M., \& Adnan, S. M. (2017). The role and impact of business communication on employee performances and job satisfactions: A case study on Karmasangsthan Bank Limited, Bangladesh. Arabian Journal of Business and Management Review, 7(3), 1-8. https:// doi.org/ 10.4172/ 2223-5833.1000301

Nasution, M. I. (2018). Peran Kepuasan Kerja dan Kepemimpinan Transformasional Terhadap Kinerja Karyawan. The National Conferences Management and Business (NCMAB) 2018, 425439.

Pawirosumarto, S., Sarjana, P. K., \& Gunawan, R. (2017). The effect of work environment, leadership 
Jurnal Manajemen Strategi dan Aplikasi Bisnis, Volume 4, Nomor. 2, 2021. 389 - 400

style, and organizational culture towardsjob satisfaction and its implication towards employee performance in Parador hotels and resorts, Indonesia.International Journal of Law and Management, 59(6), 1337-1358. https:/ / doi.org/ 10.1108/ IJLMA-10-2016-0085.

Poerwaningrum, H. E., \& Sudirjo, F. (2016). Pengaruh Kepemimpinan, Budaya Organisasi, Komitmen Organisasi dan Kepuasan Kerja terhadap Kinerja (Studi pada Guru SD. Hj Isriati Baiturrahman I Semarang). Jurnal Ilmiah UNTAG Semarang, 5(1), 1-14.

Rivai, V., \& Mulyadi, D. (2012). Kepemimpinan dan Perilaku Organisasi. In Kepemimpinan dan Perilaku Organisasi.

Riyadi, H., Utomo, B. S., \& Masatip, A. (2017). Pengaruh Komunikasi, Motivasi Kerja Dan Kompetensi Terhadap Kepuasan Kerja Serta Implikasinya Pada Kinerja Dosen Pada Perguruan Tinggi Pariwisata Swasta Di Jawa Barat. THE Journal : Tourism and Hospitality Essentials Journal, 7(2), 73. https:/ / doi.org/ 10.17509/ thej.v7i2.9014

Robbins, S. P., \& Judge, T. A. (2008). Perilaku Organisasi Jilid II. Salemba Empat. https:/ / doi.org/ 10.1097/ ACM.0b013e31821db670

Supriyatin, SY., (2014), Budaya Organisasi, Jilid 1, Program Pasca Sarjana Sekolah Tinggi Ilmu Administrasi Mandala Indonesia, Jakarta.

Supriyatin, SY., (2013), Manajemen Sumber Daya Manusia, Diktat Kuliah, Program Pasca Sarjana STIE IPWIJA, Jakarta.

Sutrisno, E. (2009). Manajemen Sumber Daya Manusia Edisi pertama. Jakarta: Kencana Prenada Media Group.

Taurisa, C. M., \& Ratnawati, I. (2012). Analisis Pengaruh Budaya Organisasi dan Kepuasan Kerja terhadap Komitmen Organisasional dalam meningkatkan Kinerja Karyawan. Jurnal Bisnis Dan Ekonomi (JBE). Diakses tanggal 23 Maret 2020. https:/ / doi.org/ ISSN: 1412-3126

Terry, George R, (2006), Asas-Asas Manajemen, Edisi Kedelapan, Cetakan Kelima, Alih Bahasa : Winardi, PT. Alumni, Bandung.

Tika, P. (2006). Budaya Organisasi dan Peningkatan Kinerja Perusahaan. Jakarta. PT. Bumi Aksara.

Tumbelaka, S. S. X, Habsji, T. Al, \& Nimran, U. (2016). Pengaruh Budaya Organisasi Terhadap Kepuasan Kerja, Komitmen organisasional dan Intention to Leave (Studi pada Karyawan PT.Bitung Mina Utama). Jurnal Bisnis Dan Manajemen, 3(1), 94-108.

Veithzal, R. (2008). Kepemimpinan dan perilaku organisasi. Jakarta: PT. Raja Grafindo.

Widyawatiningrum, E., Suryadi, U., \& Rizal, (2015). Pengaruh Motivasi, Kepemimpinan, Budaya Organisasi Terhadap Kinerja Dengan Kepuasan Sebagai Variabel Intervening Di PTPN X Jember16(2), 127-136.

Yukl, G. (2012). Effective leadership behavior: What we know and what questions need more attention. Academy of Management Perspectives. https:// doi.org/ 10.5465/ amp.2012.0088

Zarvedi, R., Yusuf, R., \& Ibrahim, M. (2017). Pengaruh Kepemimpinan, Budaya Organisasi Dan Kompetensi Terhadap Kinerja Pegawai Serta Implikasinya Pada Kinerja Sekretariat Kabupaten Pidie Jaya. Jurnal Perspektif Ekonomi Darussalam, 2(2), 201-217. https:/ / doi.org/ 10.24815/jped.v2i2.6694

\section{Competing interests}

The authors declare that they have no competing interests

\section{Funding.}

Sumber pendanaan dalam penelitian ini adalah berasal dari dana penelitian internal Fakultas Ekonomi dan Bisnis Universitas Nasional 